NBER WORKING PAPER SERIES

\title{
PUSH AND PULL: DISABILITY INSURANCE, REGIONAL LABOR MARKETS, AND BENEFIT GENEROSITY IN CANADA AND THE UNITED STATES
}

\author{
Kevin Milligan \\ Tammy Schirle \\ Working Paper 23405 \\ http://www.nber.org/papers/w23405 \\ NATIONAL BUREAU OF ECONOMIC RESEARCH \\ 1050 Massachusetts Avenue \\ Cambridge, MA 02138 \\ May 2017
}

This paper was prepared for the conference "Public Policies in Canada and the United States," held in Gatineau Quebec, October 27-28, 2016. We would like to acknowledge David Card, Phil Oreopoulos and Employment and Social Development Canada for organizing the project. We thank Claude Lavoie and other participants for their comments on the paper. We also thank John Rietschlin and others at Employment and Social Development Canada for their assistance with CPP-D administrative data. The views expressed herein are those of the authors and do not necessarily reflect the views of the National Bureau of Economic Research.

At least one co-author has disclosed a financial relationship of potential relevance for this research. Further information is available online at http://www.nber.org/papers/w23405.ack

NBER working papers are circulated for discussion and comment purposes. They have not been peer-reviewed or been subject to the review by the NBER Board of Directors that accompanies official NBER publications.

(C) 2017 by Kevin Milligan and Tammy Schirle. All rights reserved. Short sections of text, not to exceed two paragraphs, may be quoted without explicit permission provided that full credit, including $(\odot$ notice, is given to the source. 
Push and Pull: Disability Insurance, Regional Labor Markets, and Benefit Generosity in Canada and the United States

Kevin Milligan and Tammy Schirle

NBER Working Paper No. 23405

May 2017

JEL No. H53,I38,J21

\begin{abstract}
Disability insurance take-up has expanded substantially in the past twenty years in the United States while shrinking in Canada. We empirically assess these trends by measuring the strength of the 'push' from weak labor markets versus the 'pull' of more generous benefits. Using an instrumental variables strategy comparing benefit changes across country, age, and year, we find that both benefits and regional wages matter. Simulations suggest that the upswing in disability insurance take-up in the United States would be reversed, dropping the caseload by one third, if benefits and wages had followed the growth path observed in Canada.
\end{abstract}

\author{
Kevin Milligan \\ Vancouver School of Economics \\ University of British Columbia \\ 6000 Iona Drive \\ Vancouver, BC V6T 1L4 \\ CANADA \\ and NBER \\ kevin.milligan@ubc.ca \\ Tammy Schirle \\ Department of Economics \\ Wilfrid Laurier University \\ 75 University Avenue West \\ Waterloo ON N2L 3C5 \\ CANADA \\ tschirle@wlu.ca
}




\section{Introduction}

The emerging debate about the economic and social withdrawal of prime-age workers encompasses several possible contributing factors, ranging from trade, to technology, to income support policy. ${ }^{1}$ Public disability insurance is often raised in this context in the United States, in light of the sharp upward trend in the use of disability insurance since the early 1990s. In Figure 1 we graph the incidence of disability insurance benefits in the United States and Canada using administrative sources, separately for men and women over ages 30-59 from 1970 to 2015. Since 1990 in the United States, the disability insurance take-up rate for men has increased by two thirds, while for women it has more than tripled. In Canada, disability insurance uptake rose through 1995, and then fell back slightly for men, while leveling out for women. Coile, Milligan and Wise (2016) document declining disability insurance take-up rates in most European countries. Through the 1990s and 2000s, Sweden, the UK, Italy and Germany are characterized by the same inverted U-shaped pattern in disability insurance participation among older men as in Canada. It is the United States that is the clear outlier on disability insurance among OECD countries.

The contrasts across Canada and the United States are striking, and reveal an opportunity to explore the causes of the observed disability insurance trends. In particular, two leading explanations in the US literature can be assessed by comparing the US to Canada. First, the decline of mid-skill employment opportunities might 'push' workers onto

\footnotetext{
${ }^{1}$ For example, consider evidence in Beaudry, Green and Sand (2016), Green and Sand (2015), Acemoglu and Autor (2011) and Autor and Dorn (2013). Recent public debate can be found in Summers (2016) which discusses the book "Men without Work" (Eberstadt 2016).
} 
disability insurance. While Canada has not been immune to labor market pressures on lower-skilled workers, the resource boom of the 2000s had a beneficial impact on these workers in some regions of Canada. The resulting earnings gap between some Canadian and American regions could explain some of the differences in trends. Second, benefit generosity might 'pull' workers into disability insurance receipt. In the United States, benefit generosity has increased over the last twenty years, while declining in Canada. Again, this basic explanation could contribute to the differences in disability insurance uptake in Canada and the US.

Previous evidence strongly suggests that both the stringency with which fitness to work is assessed and also the generosity of benefits has some influence on labor force withdrawal. ${ }^{2}$ In the US, Autor and Duggan (2003) found reduced screening stringency, declining demand for less-skilled labor, and increases in replacement rates from disability insurance increased the likelihood of high school dropouts to exit the labor force. Duggan and Imberman (2009) showed that eligibility changes, economic conditions and increased replacement rates were important factors in the growth of SSDI growth among men, while increased coverage because of higher employment was important among women. Maestas, Mullen and Strand (2013) have found benefit receipt by those on the margin of disability benefit entry substantially reduces employment. Maestas, Mullen and Strand (2015) show that disability insurance claims tend to rise in times of high unemployment (although many applications for disability insurance induced by the Great Recession were denied). In Canada, the evidence is more mixed. Gruber (2000) examines benefit

\footnotetext{
${ }^{2}$ For older workers, European evidence finds that older workers may use disability insurance as a pathway to early retirement. See Coile, Milligan and Wise (2016) for a discussion of older workers.
} 
generosity in Quebec relative to the rest of Canada prior to 1987 and finds a large increase in labor market non-participation in response to higher benefits. Campolieti (2004), however, examines an earlier increase in Quebec's benefit generosity (in 1973) and finds no such relationship. Campolieti and Riddell (2012) examine earnings exemptions and found these have an effect on the likelihood of disabled beneficiaries to work, but do not affect flows on or off disability rolls.

Our paper aims to assess the role of both the 'push' and 'pull' factors on disability insurance take-up in the United States and Canada. We use large-scale microdata surveys of incomes and labor market activity over the period 1996 to 2016 and a quasiexperimental research design that exploits both policy differences and international wage trends. Our contribution to the literature examining the impacts of disability insurance programs begins with our ability to separately identify the effects of benefit levels and earnings opportunities on disability insurance take-up rates. Moreover, our use of Canada as a control group strengthens our quasi-experimental approach to identifying these 'push' and 'pull' factors.

We find that both push and pull factors matter significantly in explaining the take-up of disability insurance benefits. The differing trends in regional labor markets and benefit generosity can explain almost all of the upswing in disability insurance participation in the United States - if wages and benefits had followed Canadian patterns, disability insurance uptake would be about 32 percent lower than currently observed. 
We begin with a description of the disability insurance programs in Canada and the United States. Following that, we explore the trends in earnings, disability insurance benefits, and disability insurance uptake across subgroups in the two countries. We then proceed to describe our empirical strategy and present our main empirical results. Finally, we simulate paths for disability insurance uptake using counterfactual paths for earnings and benefits based on the actual observed trends in the neighboring country.

\section{Disability Insurance Programs and Earnings}

Disability insurance arose as part of the social insurance structure of industrialized countries through the $20^{\text {th }}$ century, driven by a desire to provide income support to those no longer able to work because of poor health. Typically, these plans are contributory with benefits geared to some function of lifetime earnings. The Canadian and American public disability insurance plans conform to this international pattern in general, but there are subtle differences in how the programs are implemented. We set out key details of the Canadian and American public disability plans in this section, with an emphasis on plan details after 1996. Further details can be found in Baker and Milligan (2012) Milligan and Schirle (2016), Milligan (2012), Coile (2016) and Campolieti and Riddell (2012).

\section{A. Canada / Quebec Pension Plan Disability Insurance}

The Canada Pension Plan (CPP) was introduced in 1966, with both a retirement and also a long-term disability insurance component (referred to as CPP-D). Workers began making contributions in 1967 and disability benefits began in 1970. Quebec administers its own disability insurance program as part of the Quebec Pension Plan (QPP-D), which 
operates in the province of Quebec in parallel to the CPP. Since the late 1980s, the two disability insurance programs have been nearly identical in terms of their benefit formulas, with some small differences in eligibility criteria.

The disability benefit has two components. The first component offers a flat-rate benefit that is indexed to the consumer price index. In 2016, the flat rate portion offered CAD \$471 per month. The second component offers 75 percent of what would be an individual's retirement benefit, allowing for a truncated contribution period to the time of disability claim. Retirement benefits are calculated as 25 percent of average covered earnings. In 2016, this second component reached a maximum of CAD\$819 per month. The CPP-D and QPP-D programs also offer a child benefit, adding CAD\$238 and CAD \$76 per month, respectively, for those with dependent children (under age 18 or students age 18-25).

To determine average earnings (the second component of the disability benefit), one begins by establishing the relevant contribution period, which is the time since the individual turned 18 or 1966 (whichever is later). To update nominal earnings in the contribution period, earnings are multiplied by the ratio of a five-year average of the earnings cap to each year's earnings cap. This earnings cap, known as the year's maximum pensionable earnings (YMPE), was CAD\$54,900 in 2016 and is indexed annually to a measure of average wages. Until 1997, a three-year average of the earnings cap was used to update earnings. This was adjusted to a four-year average in 1998 and then the five-year average in 1999. Individuals may drop years from the contribution 
period associated with care of their young children. Some low-earnings years are then dropped for individuals with at least 10 years in their contribution period. Until 2011, $15 \%$ of months were dropped. This increased to $16 \%$ for $2012-13$ and $17 \%$ for $2014-15$. The remaining contribution period is used to obtain the average indexed monthly earnings (AIME).

An individual's benefit from CPP-D and QPP-D can be summarized as

(1) Disability Benefit $=$ Flat rate $+0.1875 *$ AIME + child benefits

For the CPP-D, eligibility for the benefit requires that an individual has a disability that is both "severe and prolonged". ${ }^{3}$ Severe implies the disability regularly stops the individual from doing any type of substantially gainful work. Since 1995, the medical adjudication process does not account for socio-economic factors in assessing disability. The QPP-D also has a medical adjudication process, but appears to allow greater flexibility in the process. This 1995 change coincides with a sharp change in the timepath of CPP-D uptake as seen in Figure 1.

Eligibility also depends on labor force attachment. Until 1996, individuals had to contribute to CPP in two of the previous three or five of the previous ten years to qualify. In 1997, eligibility was restricted to those with contributions in four of the last six years. In 2005, this requirement was loosened a bit, allowing those with 25 years of

\footnotetext{
${ }^{3}$ Guidelines are offered from ESDC at http://www.esdc.gc.ca/en/cpp/disability/index.page.
} 
contributions to CPP and contributions in three of the last six years to be eligible. In Quebec (since 1993), individuals are eligible if they made contributions in two of the previous three or five of the previous ten years.

In Canada, there are few other public programs that offer long-term disability insurance so broadly. At the federal level, the Employment Insurance program offers up to 15 weeks of unemployment insurance benefits (with up to 55\% earnings replacement) to individuals who cannot work because of sickness or injury. For disabled individuals who continue to work with relatively low income, some financial assistance is offered through the Working Income Tax Benefit Disability Supplement (a refundable tax credit). Otherwise, disability programs vary across provinces. Individuals with work-related injuries may qualify for benefits under provincial workers' compensation programs. Income-tested disability benefits are also offered through income support programs (social assistance or welfare) that typically do not depend on work histories.

\section{B. Social Security Disability Insurance}

Social Security provisions for disability insurance (SSDI) were introduced in 1950, with major reforms enacted in the 1970s and 1980s. The main disability benefit formula has not changed substantially since and primarily depends on an individual's average covered earnings.

To determine average earnings, covered nominal earnings in the individual's earnings history (up to the annual maximum taxable earnings, or AMTE, which was US\$118,500 
in 2016) are multiplied by the ratio of average wages two years prior the claim (or age 60, whichever is earlier) to past average wages. ${ }^{4}$ More recent wages are not adjusted. Individuals can drop out up to $20 \%$ (maximum 5 years) of low earnings years from their history. The remaining period (at least two years) is used to obtain their average indexed monthly earnings (AIME).

This average then enters a progressive non-linear benefits formula, summarized as

$$
\begin{aligned}
& \text { Disability Benefit }=0.9 * \min (\text { AIME, BEND1) } \\
& +0.32 * \max (\min (A I M E-B E N D 1, B E N D 2-B E N D 1), 0) \\
& \quad+0.15 * \max (A I M E-B E N D 2,0)
\end{aligned}
$$

BEND1 and BEND2 are "bend points" in the benefit formula. In 2016, the first bend point was set at US $\$ 856$ per month and the second was set at US $\$ 5,157$. These bend points are indexed to average wages. This reliance of the formula on average wages is particularly noteworthy since income growth among the highest earners has increased average wages while median wages have stagnated.

Eligibility for the SSDI benefit requires that a person's disability prevents him or her from doing work done before, and is unable to adjust to other work because of the medical condition. Furthermore, the disability is expected to last for at least one year or result in death. Consideration is given to socioeconomic factors, including age, education,

\footnotetext{
${ }^{4}$ The relevant national average wage can be found in the Social Security Administration's Annual Statistical Supplement, Table 2.A8, found at https://www.ssa.gov/policy/docs/statcomps/supplement/2015/2a8-2a19.html.
} 
past work experience, and transferable skills in determining ability to adjust to other work.

Eligibility also depends on previous labor force attachment. Requirements depend on the age at the time of making a claim, but generally need to have worked in 5 of the previous 10 years.

The availability of other disability benefit programs varies by state, but is broadly similar to programs in Canada. Some short-term disability insurance is offered through unemployment insurance programs, covering non-work related illness or injury. For example, California offers up to 52 weeks of disability benefits with up to $55 \%$ of earnings replacement. ${ }^{5}$ For work-related injuries, individuals may seek benefits under state-level workers' compensation programs. For disabled individuals lacking strong work histories, individuals may qualify for Supplemental Security Income (a federal program).

\section{Canada-U.S. Benefit Differences}

One of the key differences between CPP-D and SSDI is the adjudication of claims. In Canada, since 1995, eligibility is primarily based on a medical assessment. While a disability must prevent one from working to be eligible for CPP-D, little consideration is otherwise given to socioeconomic factors after 1995. The downturn in CPP-D benefit

\footnotetext{
${ }^{5}$ More information for California can be found at http://www.edd.ca.gov/Disability/About the State Disability Insurance (SDI) Program.htm.
} 
receipt after 1995 is in part attributed to the 1995 reform in the medical adjudication

process - in particular the more stringent screening led to a decrease in hard-to-diagnose conditions such as musculoskeletal disorders (Campolieti 2002; 2006). In contrast, the United States loosened the stringency of its screening in 1984 (see Coile 2016) which is one of the forces underlying the surge in SSDI take-up in the United States (Autor and Duggan 2006).

Another key difference between the CPP-D, QPP-D, and SSDI lies in their benefit formulas. While the CPP-D and QPP-D formula is a simple linear function of earnings, the SSDI formula is progressively non-linear as the replacement rate increases at each bend point. Furthermore, SSDI covers a much higher level of earnings than does CPP-D and QPP-D. Over the period we study since 1996, however, the general structure of the benefit formulas has not changed substantially in either country.

In the CPP-D, QPP-D, and SSDI formulas, key parameters are automatically adjusted, and are indexed to a measure of average wages. It is important to consider, then, that real average wages have trended quite differently in each country. Because average wages affect the benefit formula mechanically, the differential trends in average wages have a mechanical impact on benefit formulas. These trends are discussed in later sections.

\section{Data}

We use several data source in this study. First, to describe trends in disability insurance take-up, we rely primarily on administrative data and population estimates. The Social 
Security Administration (SSA, 2015) provides the historical estimates of the number of disability insurance recipients, by sex and age in the United States. We use population estimates from the Census Bureau to form the denominator of our take-up rates. ${ }^{6}$ Administrators of the Canada Pension Plan published estimates of the number of disability insurance recipients, by age and sex, in statistical bulletins until 2011 (HRSDC, 2011). We obtained more recent tabulations directly from Employment and Social Development Canada, responsible for the administration of CPP and use population estimates provided by Statistics Canada. ${ }^{7}$

For the bulk of our analysis, we use pooled cross sections of the U.S. Current Population Survey’s (CPS) March Supplements (1996-2016) and Canada's Survey of Labour and Income Dynamics (SLID) public-use files (1996-2011) and Canadian Income Survey (CIS) public-use files (2012-2014). Each of the surveys provides basic demographic information (age, education, region of residence) and detailed income information. Our main sample includes individuals aged 25-59. We also make use of the Canadian Labour Force Survey (1996-2016) for our analysis of labor supply, since it gives us more detail on labor market attachment.

We start our analysis in 1996 for several reasons. First, it places our analysis after the 1995 reforms to CPP-D stringency in Canada. ${ }^{8}$ Second, the data we use for Canada is

\footnotetext{
${ }^{6}$ The source is Population Estimates Program data provided on the website: http://www.census.gov/programs-surveys/popest.html.

${ }^{7}$ The population estimates are from the CANSIM database, table 051-0001.

8 According to OCA 2016 (Chart 11), new claims peaked in 1992, and then declined as the economy recovered following the 1990-91 recession. Moreover, OCA (2016) estimates of disability termination rates indicate the majority of CPP-D benefits terminate within the first and second year of benefit receipt.
} 
available starting in 1996. Third, 1996 is early enough to capture most of the upswing in SSDI for both men and women in the United States.

From the CPS and SLID/CIS surveys, we can observe the receipt of benefits from Social Security (for the US) and Canada/Quebec Pension Plan (for Canada). One important shortcoming of our data sources is that they do not always distinguish between disability benefits, retirement benefits, and survivor benefits. Our age selection criterion has an upper limit at age 59, which rules out retirement benefits as a possibility in either Canada or the United States. However, survivor benefits could be payable to those with a deceased spouse, even if the survivor is under age 60. We address how survivor benefits may affect our analysis by performing robustness checks. In particular, our US data from 2001 forward reports SSDI receipt separately, so we can assess the importance of using the more general SS variable. For men, about 82 percent of Social Security benefits in the age range in our data represent disability insurance; for women it is about 69 percent. The lower proportion for women reflects the higher incidence of survivor benefits for women than for men.

The CPS and SLID/CIS allow us to account for several characteristics of individuals in our analysis. We account for demographic characteristics using available variables on marital/common law status, gender, and education categories. ${ }^{9}$ We form age groups with five-year age clusters, ranging from 25-29 to 55-59. We also make use of regional

Overall, observed changes in Canadian disability receipt after 1996 appear largely unconnected to the 1995 change in eligibility criteria.

${ }^{9}$ The three education categories are less than high school, high school graduate and some post-secondary college/university degree or more. 
variation in our data. For Canada, we use the five regions delineated by Statistics

Canada. ${ }^{10}$ For the United States, we use the nine census divisions. ${ }^{11}$ In the rest of this paper we refer to all of these fourteen areas as 'regions'.

\section{Trends in Earnings, Benefits, and DI Takeup}

In this section, we examine the trends in earnings and in disability insurance benefits in order to provide context to the disability insurance uptake decision and to motivate our empirical strategy. For earnings, we show the differences through time across education level and geography, while for benefits we focus on the difference in the benefit generosity across age groups. The lower is earnings growth, the more we expect weak earnings prospect to push individuals into DI receipt. The higher is benefit growth, the more we expect individuals to be pulled into DI receipt.

We begin with growth in median earnings across education groups in Figure 2, using both sexes and ages 25-59 separately for Canada and the US. We include only those observations with positive earnings. For Canada in panel A, the dashed line represents movements in the 3-5-year average YMPE that is used in the adjustment of earnings histories (indexed here in the graph to $1996=100$ ). We see that the real value of the YMPE was falling slightly through most of the 2000s, only recovering to its 1996 levels by 2013. This trend in YMPE largely reflects a period of low wage inflation, relative to price inflation, in the early 2000 s. The flat rate portion of the disability benefit is held

\footnotetext{
${ }^{10}$ The Canadian regions are: Atlantic, Quebec, Ontario, Prairies, British Columbia.

11 The US Census divisions are: New England, Middle Atlantic, South Atlantic, East South Central, East North Central, West North Central, West South Central, Mountain, Pacific.
} 
constant in real terms since it moves with the consumer price index, and the earningsrelated portion of the benefit moves with average wages. A lack of movement in the real value of the YMPE will translate into a lack of movement in the real value of disability benefits. Earnings using our measure grew more quickly than the YMPE for most of the time period, with the higher-educated groups showing the lowest gains. ${ }^{12}$

In Panel B of Figure 2 we show the same data for the United States. The dashed line represents movements in the first bend point of the benefit formula. Both bend points in the formula move with the same measure of average wages, also used to update earnings histories. In the United States, we see that average wages rose substantially, by more than $20 \%$ over the $1995-2015$ period. This increase in the bend point means that the real value of disability benefits, by virtue of the benefit formula, also increased. For earnings, we see a separation between the Social Security bend point and median earnings across education groups starting in about 2000. After 2000 — and especially after 2007-the median earnings started to fall in each education category, with the biggest decrease in the lower education categories.

The regional dimension of earnings growth uncovers vast differences. Again, we put the two sexes together and use the age 25-59 sample of individuals with positive earnings. In Figure 3, we draw a separate line for each of the five Canadian regions (dashed lines) and the nine US census divisions (solid lines). The growth is fairly uniform until 2002 when

\footnotetext{
${ }^{12}$ The YMPE is based on the year-over-year (using June numbers) growth in the industrial aggregate average wage. This industrial aggregate covers workers of all ages, does not include the self-employed, and is an average. So, the measure is not exactly aligned with what we measure in Figure 2 using the SLID/CIS. This may explain why the YMPE trails the median earnings in each category for men and women.
} 
some regions begin strong growth and others fall off. We have highlighted in thick lines the Canadian Prairie region and the US East North Central division of the Midwest region in order to contrast the extreme regions. ${ }^{13}$ By 2014, the Canadian Prairie region had seen earnings growth of 42 percent over 1996 levels, while the East North Central division saw only 10 percent growth over 1996 levels by 2016, and had still not surpassed the earnings level seen in 2002. Within Canada, the Atlantic region saw nearly as high growth as the Prairies, while the other regions more resembled the US. The best performers in the US were concentrated in the West.

We now turn to the time patterns of disability benefits. In Canada, the main change in the formula over time was a small decline, then recovery in the YMPE. In the United States, the average income indexing of the SS bend points is the largest source of benefit variation. These differences have a different impact for younger workers and older workers because of the way that low-earnings years are dropped-older workers may drop more years and therefore receive a higher benefit. We simulate benefits for a fictitious Canadian and American worker, using the same common earnings history. ${ }^{14} \mathrm{We}$ apply each year's formula parameters to this common earnings history, adjusted only for inflation. This delivers a simulated benefit that embodies only changes in the legislated benefit rules over time and country, rather than changes in earnings.

\footnotetext{
13 The Prairie region includes Alberta, Saskatchewan, and Manitoba. The East North Central division of the Midwest regions includes the states of Wisconsin, Illinois, Indiana, Michigan, and Ohio.

${ }^{14}$ For the common earnings history, we take the earnings history for the 1950 male birth year cohort in the United States. We then update it for inflation to cover all relevant birth cohorts in Canada and the United States.
} 
We graph the benefits for this common earnings history in Figure 4, separately for Canada and the US. There are separate lines for 1996, 2006, and 2016 shown across age groups; both panels have the same y-axis to ensure ready comparisons across the two countries. We use 2016 US dollars for both countries. For Canada in Panel A, benefits deteriorate between 1996 and 2006, before rebounding in 2016. The gain for a 59-year old in 2016 over 2006 is $\$ 659$ in annual benefits, or 5.9 percent. These changes are driven by the changes in the YMPE across time. In the US in Panel B of Figure 4, there is a strong increase in benefits between 1996 and 2006, and a more modest increase to 2016. Again, this is formula-driven through the generous indexation of the bend points. The total gain from 1996 to 2016 for a 59 -year old is $\$ 3,553$, which is 18.1 percent over the 1996 level.

To close the analysis of trends, we turn back to the DI take-up rate. In Figure 1 (discussed in the introduction) we showed men and women had very different paths for the uptake of DI benefits across Canada and the United States, with Canadian uptake remaining relatively flat while uptake grew substantially in the United States. Here, we break down the take-up rate by education group, using the sample of age 25-59 and both sexes. Figure 5 shows the take-up rate for Canada, with the level in 1996 set to 100. There was some increase in the take-up rate of around 30 percent between 1996 and 2001 for all education groups, but since then the rates have diverged. The take-up rate for the middle education group has stayed roughly constant, while for the top- and lower-education groups the take-up rate has dropped. The bottom panel of Figure 5 reveals a starkly different pattern in the United States. For the middle-education group, take-up increased by 64 percent in 
2016 compared to 1996 , with a more modest 30 percent increase for the high-education group, and a decrease for the lowest-education group.

Overall, this descriptive analysis has exposed strongly different trends in earnings by region and education group, and substantial changes in the benefits delivered by the US SSDI formula, but much less policy variation in Canada. There has also been a large increase in DI uptake in the US, driven by middle-educated Americans. We take this information as context for the formation of our empirical strategy in the next section where we exploit differences across these groups.

\section{Empirical strategy}

Our empirical strategy is quasi-experimental, exploiting variation in policy and international (Canada-US) earnings trends. At the core of our strategy is a differencing framework, within which we use instrumental variables to improve our estimates. We lay out our methods in this section, starting with the estimating equation of interest, then our measurement of disability insurance benefits, moving on to the regional earnings measure and then summarizing our identification strategy.

\section{A. Estimating Equation}

We think of individuals comparing the utility associated with taking up disability insurance against the utility associated with not taking up disability insurance (which we term $\left.D I^{*}\right)$. The individual's decision will depend primarily on the replacement rate offered by the disability insurance program, which is comprised of two parts-the 
disability benefit offered $(\ln D B)$ and their potential earnings in the local labor market (lnEarn). The individual's decision to take up disability insurance can be described by the equation

$$
\text { (3) } D I_{i t}^{*}=\beta_{0}+\beta_{1} \ln D B_{i t}+\beta_{2} \operatorname{lnEarn}_{i t}+\varepsilon_{i t} \text {. }
$$

We estimate the equation using a linear probability model.

$$
\text { (4) } D I_{i t}=\beta_{0}+\beta_{1} \ln D B_{\text {gearit }}+\beta_{2} \operatorname{lnEarn}_{\text {gearit }}+X_{i t} \Gamma+\varepsilon_{i t}
$$

Where $D I_{i t}=1$ when we observe receipt of CPP/QPP-D or SSDI disability benefits and zero otherwise. As described in more detail below, we do not observe all individuals' potential disability benefits or earnings. Rather, we calculate the benefits that individuals in the same gender-age-education-region cell would qualify for at time $t$. Similarly, the earnings variable will represent average earnings for individuals in the same gender-ageeducation-region cell at time $t$. In the vector $X_{i t}$ we include dummy indicators for marital status, gender, education, region, age, and year. Also in $X_{i t}$ is the log mortality rate, as an objectively measurable control for health differences across gender, age, and country.

\section{B. Disability Insurance Benefits}

The disability insurance benefits for which one is eligible depends on one's earnings history, the benefit formula in a given year, and current age. The earnings history matters because benefits are calculated explicitly accounting for the pattern of earnings over one's lifetime. The benefit formula matters because it translates the earnings history into a benefit. The age matters because younger people have a smaller number of potential years in work, requiring them to keep more lower-earning years in their earning history, 
and thus receive a smaller benefit through the application of the formula, given the earnings history.

Calculating the benefit as a function of one's own earnings history introduces potential endogeneity to the benefit calculation. Those who may have a latent disability may have a weaker earnings history, leading to a smaller potential benefit and also a higher likelihood of receiving benefits. To overcome this potential endogeneity problem, we calculate a simulated benefit using a common earnings history for all peoplespecifically, the average earnings for the cohort born in 1950. This simulated benefit varies only by three exogenous factors - the system (Canada or the US), the year, and the age. We use this simulated benefit as an instrument to predict the calculated individual benefit.

In our empirical implementation, we control directly for each of these three factors (system, year, and age) along with the two-way interactions of each of these three factors. In this way, identification is driven by exogenous variation in the legislation.

\section{Regional Earnings}

The second key variable we wish to relate to disability insurance take-up is the potential earnings on offer to workers. We measure potential earnings as the average earnings within cells defined by age group, education, gender, region, and year. Potential earnings, however, reflect supply conditions such as human capital, experience, and other attributes, which may not be observable. If these supply-side attributes are correlated with 
factors that also influence disability insurance take-up, we need a way to isolate variation in earnings from these other endogenous factors. For this reason, we implement an instrumental variables strategy, which depends on national earnings trends and fixed local characteristics. This 'Bartik-style' instrument strategy is commonly used in this circumstance. ${ }^{15}$ The Bartik instrument is constructed as

$$
\text { (5) } \text { Bartik }_{\text {geart }}=\sum_{k=1}^{3} \text { Earn }_{\text {kgea }(-r) t} * \text { Share }_{\text {kger } 95}
$$

Where Earn represents average earnings among individuals in industry $k$ (primary, manufacturing or other), in all regions of Canada and the United States other than region $r$. The variable Share represents industry $k$ 's share of the 1995 workforce in each region in each of the $k$ sectors. The regional earnings and industry shares are used to construct the composite earnings measure Bartik, a weighted average of the sector level earnings with each region's initial sector shares used as weights. In our implementation, we repeat this Bartik composite earnings calculation separately for cells defined by gender, age, and education level; in each case using the national sector trends and initial regional sector shares. This instrumental variable strategy isolates the trends in earnings from regionallyvarying unobserved factors.

\section{Identification}

Our instruments are based on variation across region, year, education, age, and gender. We include in our estimating equation the main factors underlying the variation for each of our two instrumental variable strategies. For the simulated disability benefit, we have

\footnotetext{
${ }^{15}$ Bartik (1991) developed this method of isolating changes in local labor demand and has been used in a wide range of studies including Autor and Duggan (2003), Bertrand et al. (2015), and Maestas, Mullen and Powell (2013) with further references therein.
} 
the main effects for year, age, and country. For the Bartik instrument, we have the main effects for age, gender, education, and year. By including these main effects we can separate the impact of benefits and earnings from the factors used as inputs for the calculation of the instruments.

In order to fortify our empirical strategy, we go beyond this specification by also including the second-order interactions between the main factors for each of our instruments. In this way, our strategy is best thought of as a triple-differencing approach. Specifically, for the disability insurance benefits we include the full set of interactions between age and year, year and country, and age and country. For the regional earnings, we include the full set of interactions between gender and education, education and year, and gender and year. Earlier, Figure 4 showed the extent of our policy variation across years for a given age and country. It is this variation that allows us to implement our triple-difference strategy.

\section{Measurement and Descriptive Statistics}

As described in earlier sections, we use pooled cross sections of the CPS March Supplements (1996-2016), SLID (1996-2011) and CIS (2012-2014) in our analysis. We also use the LFS (1996-2016) for our final labor supply analysis. Our primary dependent variable is an indicator for the receipt of benefits from Social Security (for the U.S.) and

Canada/Quebec Pension Plan (for Canada). Our US data from 2001 forward reports SSDI receipt separately, so we also try specifications for the US using an SSDI receipt indicators. 
Beyond the disability insurance variables, we also create several indicator variables for receipt of other government benefits. For the US, this comes from the CPS; for Canada this information comes from the SLID/CIS. We create indicators for receipt of unemployment insurance (called Employment Insurance in Canada), welfare benefits, workers' compensation, and a final indicator for receipt of any government benefits.

We also use the CPS in the United States and the Labour Force Survey in Canada to form indicator variables for attachment to the labor market. These variables are based on a question of current labor force status, and respondents fall into three mutually exclusive and exhaustive categories: employed, unemployed, out of the labor force. We further subdivided the employed indicator into two categories for whether the respondent is currently employed and at work or employed and on leave.

Our main independent variables of interest are the potential disability insurance benefits and potential earnings. We form the disability insurance variable by attaching to each observation an earnings history based on the average earnings of someone of the same gender, region, education, and year of birth cohort. ${ }^{16}$ Using this earnings history, we use a benefit calculator that incorporates the rules as they exist in each year. For potential earnings, we take the average earnings by age group, year, gender, region, and education group.

\footnotetext{
${ }^{16}$ For Canada, we use the Survey of Consumer Finances income files to extend backward to 1973, interpolating for missing years. For years before 1973, we project backward using the consumer price index. For the United States, we use the Current Population Survey back to 1966 and project backward from there using the consumer price index.
} 
We control for the demographic characteristics of each individual using available data. These controls include a dummy for marital/common law status, for gender, and a set of four dummy variables for education. ${ }^{17} \mathrm{We}$ form age group dummies by five-year age clusters, ranging from 25-29 to 55-59.

The final data we bring to the regression are mortality rates. We draw these data from the Human Mortality Database (www.mortality.org). These data are available separately for Canada and the US, by age and gender, for each year. ${ }^{18}$

We present descriptive statistics on our sample in Table 1 for several samples and a selection of our variables. Our full sample, pooling together the CPS and the SLID, comes to 2.4 million observations. There are slightly more women than men, and observations from Canada make up one quarter of our sample.

In our full sample, 3.6 percent are receiving disability insurance benefits. The rate of receipt is slightly higher for women, and one third higher in the United States than in Canada. There is a strong education gradient, with 7.2 percent of those with less than high school receiving disability insurance, compared to 1.4 percent of those with a college or university degree. Our regional earnings variable aims to measure the potential earnings available to a worker in a given region, year, education, gender and age

\footnotetext{
${ }^{17}$ The three education categories are less than high school, high school graduate + some post-high school, college/university degree or more.

${ }^{18}$ We do not have mortality data for 2015-16 for the US or from 2013-2016 for Canada. For these years, we simply extended the most recently-observed age-sex mortality rate.
} 
category. Average earnings is higher for males over females, the US over Canada, and follows the expected positive education gradient.

The projected benefits variable reports the result delivered by our benefit calculators given an earnings history depending on year of birth, education, gender, and region. The average benefits are higher for males and for those with more education, reflecting higher lifetime earnings paths for these groups. Benefits in the United States are 74 percent larger than those in Canada, reflecting benefit formula differences across the countries. This is a substantial and important difference. In the next row is the replacement rate, calculated by dividing the projected benefits by the regional earnings. In the whole sample, the replacement rate is 0.343 . It is higher for women than for men, and for lesseducated workers compared to higher-educated workers.

\section{Results and simulations}

\section{A. Regression results}

Our regression results are presented in four tables, showing how our result varies in different specifications and samples. Following that, we present the results of some simulations, which help to explore the magnitudes of our estimates.

The first results are in Table 2. Each column of the table has the results of a separate regression, with coefficients and standard errors appearing in each row. The dependent variable in the first two columns in this table is a dummy for receiving Social Security or Canada/Quebec Pension Plan benefits. Our first regression in column (1) has an ordinary 
least squares (OLS) regression that includes our two main variables of interest along with a full set of controls - including the $2^{\text {nd }}$ order interactions as described above. The resulting coefficients for both the log of regional earnings and the log of disability insurance benefits are small and statistically insignificant. The other control variables show sensible results, with lower rates of disability insurance uptake for those who are married and more highly educated. There is also a significant positive relationship between the mortality rate and benefit uptake.

The second column shows the results of implementing our instrumental variables strategy. Here, we instrument for regional earnings using the Bartik-style composite earnings variable, and for disability insurance benefits using the simulations based on a common earnings history. The results for both the regional earnings and disability insurance benefits now show the expected signs and are strongly significant. The higher are potential regional earnings, the lower is the receipt of benefits, with a 10 percent increase in earnings predicted to lead to a 0.70 percentage point drop in take-up. The positive 0.050 coefficient for disability insurance benefits suggests that a 10 percent increase in the value of disability insurance benefits would lead to a half point increase in the take-up rate.

The last two columns of Table 2 show the results of the first stage regressions in our instrumental variables implementation. Our Bartik-style composite earnings measure, which exploits national variation in earnings across industrial sectors, is a strong predictor of our regional earnings measure with a coefficient of 0.644 . For our simulated 
benefit derived from a common earnings history, we obtain a coefficient of 1.056, suggesting a strong relationship between the simulated instrument and the actual benefits for someone in that region, gender, education, age, and year category.

We display the first stage relationships in Figure 6 by collapsing the data to the regionyear level. The top panel shows the relationship between the Bartik composite earnings and observed regional earnings. There is a clear and strong relationship evident. The bottom panel depicts the simulated benefits and actual disability insurance benefits. Again, there is a clear and strong relationship. In this graph, the cluster at the bottom left are the data points for Canada, where benefit generosity is markedly lower.

The next set of results in Table 3 shows how our estimates vary across Canada and the United States separately. We also show results combing both the regional earnings and benefits variables into a replacement rate. The first column of Table 3 replicates our main result from column (2) of Table 2. In the replacement rate specification, the coefficient of 0.160 implies that a ten-point increase in the replacement rate would increase disability insurance take-up by 1.60 percentage points. With an average replacement rate of 0.343 and average take-up rate of 0.036 , the implied elasticity is 1.52 . It is useful to seek some context from other estimates in the literature to understand our result better. In a survey of the literature by Bound and Burkhauser (1999), the estimated elasticities of applications and awards for SSDI ranged from 0.2 to 1.2. So, our estimate is outside that range. Our estimate of the effects on disability benefit take-up rates may reflect substitution between programs (suggested by Autor and Duggan 2003), as SSDI may be 
more generous than unemployment insurance benefits or social assistance programs. We take up this possibility of substitution below, and also look at the ultimate impact on labor supply. In addition, our simulations will also offer a further way to gauge the plausibility of the magnitude of our estimates.

The next two columns of Table 3 show separately our results from our Canadian and US samples. In these specifications, we leave out our $2^{\text {nd }}$ order interactions because we are looking at each side of our Canada-US differencing strategy separately. The coefficient for Canada for benefits is insignificant, while for the United States the estimates are similar in magnitude to the main specification. This does not mean that the Canadian disability insurance program has no impact; it may be that there is not enough variation in Canada alone across age groups and years to identify an impact.

The last column shows the results using a different dependent variable: the receipt of SSDI rather than the more general Social Security benefit receipt we use in the other specifications. Here, the coefficients are quite similar to those in column (3), suggesting that the inclusion of survivor benefits as part of SS and CPP benefits in the construction of our dependent variable does not materially affect our results.

The next table explores the results in subsamples defined by gender and education. Again we present the results for the two main variables separately in the top half of Table 4 , and then combined into a replacement rate in the bottom half of the table. The response by men overall seems stronger than for women as indicated by the replacement rate 
coefficients of 0.180 and 0.082 . However, the coefficient for regional earnings (the 'push' factor) is much stronger for males while the coefficient for disability insurance benefits (the 'pull' factor) is stronger for females.

Looking across education groups in Table 4, the response as indicated in the replacement rate specification appears to be monotonically decreasing in education. For the lowest education group, both regional earnings and benefits matter, while for those with a high school diploma or some post-high school education are much more sensitive to the potential disability insurance benefits than regional earnings. The point estimates for those with a degree are very small. Since DI benefits replace a much larger proportion of earnings for lower and middle earners than for high earners, this gradient with education is consistent with expectations.

Finally, we turn to the broader impact beyond disability insurance receipt. We do this by looking at other government income support programs and labor supply. We have shown so far that there is a strong effect of the disability benefit replacement rate on DI take-up in Canada and the United States. However, it is also interesting to consider where the new DI recipients come from. For example, previous research has emphasized a substitution from other government programs like unemployment insurance onto DI (Autor and Duggan 2003). We do this with two sets of results, all presented in Table 5. In the top panel, we examine several additional measures of public benefit receipt, ranging from unemployment insurance to welfare receipt to workers' compensation. In the bottom panel of Table 5 we turn to direct labor supply measures. Here, rather than 
looking for inter-program substitution, we take the approach here instead of looking for the ultimate response on labor supply to observe where new DI recipients are ultimately coming from.

The income source results in Panel A of Table 5 use the full sample as before, employing the CPS for the United States and the SLID/CIS for Canada. We present the replacement rate specifications since this condenses the result into one key estimated parameter, which can be compared across dependent variables. The first column reproduces our main result from Table 2 with a coefficient estimate of 0.160 . In the second column we use an indicator for receipt of unemployment insurance income (US) or employment insurance income (Canada). ${ }^{19}$ The estimated coefficient on UI/EI is 0.045 , but it is not statistically significant.

Next is an indicator for receipt of income from a welfare program. In Canada, these provincial programs are typically referred to as Social Assistance. In the US, the CPS reports receipt of public assistance of welfare income..$^{20}$ The coefficient here is also not statistically different from zero. The fourth column shows the results for Workers' Compensation, which is also statistically insignificant. In the final column is an indicator for the receipt of any government benefit. This includes any of the benefits in columns (1) to (4), and also any other benefits. The coefficient here is a significant 0.275 . This coefficient is higher than the estimate for just SS/CQPP receipt in column (1), which is

\footnotetext{
19 These programs are very different across the two countries. The Canadian program features repeat claims for seasonal employment along with parental leave benefits. This breadth of benefit coverage leads to an average of 13.5 percent of Canadians receiving EI in our sample. The program in the United States varies by state, but the average benefit recipiency rate is much lower at 4.3 percent

20 This CPS variable (PAW-YN) includes TANF and AFDC, as well as other welfare programs.
} 
not consistent with shifting across programs. However, the standard error in column (5) is fairly large and the 95 percent confidence interval here encompasses the 0.160 estimate from column (1).

Panel B in the lower half of Table 5 looks at the labor supply results. The data here for the US remains the CPS, but for Canada we switch to the Labour Force Survey (LFS). We do this because the LFS has current labor supply variables comparable to the CPS, while the SLID/CIS focus on annual measures. Across the table we present five categories of labor supply. The first is whether the respondent is employed; the next two break this down into those who are employed and at work and those who are employed but absent (for reasons such as illness or disability, family responsibilities, vacation, or a labor dispute). The final two columns show results using unemployed and not in the labor force. The first, fourth, and fifth categories are mutually exclusive and exhaustive.

The results for employment are presented in the first column of Table 5. The point estimate of 0.004 is very small and also statistically insignificant. The next two columns break down employment into those at work and those absent from work. Here we see a shift implied by the point estimates from being employed at work to being employed and absent from work. However, only the $2^{\text {nd }}$ of these effects is statistically significant. The final two columns look at unemployment and being out of the labor force. Again, the point estimates here reveal a substantial shift from unemployment into being out of the labor force. The magnitude here is plausible, but this shift is not strongly statistically significant. 


\section{B. Simulations}

In order to gauge the magnitude of our results, we present some counterfactual simulations based on our main specification in Table 2, column (2). To form the counterfactual, we take the initial 1996 values for benefits and regional earnings and impose the growth rates for these variables coming from a different region or country. This allows us to illustrate the impact of the push and pull factors on disability insurance uptake according to our estimates.

The simulations appear in Figure 7. In the top panel, we take the baseline SSDI uptake in the CPS for the United States. We then impose a counterfactual path for earnings in all regions, using the earnings growth rate from Canada. This short-dashed line is about even with the baseline until 2005, reflecting similar earnings growth in Canada and the United States in the late 1990s and early 2000s as seen earlier in Figure 3. In the later years, higher earnings growth in Canada pulls the predicted SSDI participation rate under the baseline as the higher earnings moves more people off SSDI. We then additionally impose that benefits follow the growth rate for Canadian benefits, instead of the actual path that had benefits growing substantially in the United States. We graph this with the long dash, and the effect is apparent - the time path for SSDI uptake is now slightly downward at some contrast to the upward trajectory in the baseline. Much of this happens between 1996 and 2006, as the benefit growth in the United States was concentrated in this period as seen earlier in Figure 4. By 2014, the gap between the baseline and the wage and benefits simulation reaches 1.1 percentage points. 
We refine this analysis by moving from countries to regions in the bottom panel of Figure 7. Here, we impose the wage growth and benefit growth of the East North Central Census Division of the Midwest Census region of the United States onto the Prairie region of Canada. ${ }^{21}$ As seen in Figure 3, this US region had very weak earnings growth of 10 percent over this period, while this Canadian region had very high earnings growth of over 40 percent. The baseline is graphed with a solid line and shows a decline of over 1.5 percentage points between 1996 and 2014. When Midwest earnings growth is applied to the Canadian Prairies in the short-dashed line, there is little difference before 2005, when the sharp divergence in earnings drives the DI participation rate higher. Moving from the short-dashed line to the long-dashed line, we apply the benefit growth rate of the US Midwest to the Canadian Prairies. Again, this gap is large in particular between 1996 and 2006. Overall, the gap by 2014 is 2.7 percentage points.

These simulations provide two strong conclusions. First, the magnitude of our estimated coefficients for regional earnings and benefit generosity is sufficient to reverse the observed trend differences between Canada and the United States in disability insurance uptake. Second, both the 'push' and 'pull' factors are important, although it is the pull of benefits more in the first decade of our analysis while the push of weak labor markets is more important in the more recent decade.

\footnotetext{
${ }^{21}$ For the rest of this section we refer just to 'Midwest' to ease the discussion. But for this analysis we use just the East North Central Census Division. The results look very similar if the whole Midwest Census Region is used.
} 


\section{Conclusions}

In this paper, we explore the pull of benefit generosity and the push of regional labor market conditions on the take-up of disability insurance benefits in Canada and the United States. While disability insurance uptake has grown remarkably over the last twenty years in the United States, it has shrunk in Canada. Using an instrumental variables strategy exploiting policy variation and international earnings growth trends, we

find that both push and pull factors matter and can substantially explain the trend differences in disability insurance take-up rates in Canada and the US. If the US had experienced Canadian earnings growth and benefit generosity changes between 1996 and 2016, SSDI take-up would fall by about one third from today's levels. While disability insurance is only one factor in the greater puzzle of labor force withdrawal by middleskill middle-age workers, our results here suggest it may play some role. 


\section{References}

Acemoglu, Daron, and David Autor. "Skills, tasks and technologies: Implications for employment and earnings." Handbook of labor economics 4 (2011): 1043-1171.

Autor, David, and David Dorn. "The growth of low-skill service jobs and the polarization of the US labor market." The American Economic Review 103, no. 5 (2013): 1553-1597.

Autor, David H., and Mark G. Duggan. "The rise in the disability rolls and the decline in unemployment." The Quarterly Journal of Economics (2003): 157-205.

Autor, David H. and Mark G. Duggan. "The Growth in the Social Security Disability Rolls: A Fiscal Crisis Unfolding," Journal of Economic Perspectives 20, No. 3 (2006): $71-96$.

Baker, Michael, and Kevin Milligan. "Disability insurance programs in Canada." In Social Security Programs and Retirement around the World: Historical Trends in Mortality and Health, Employment, and Disability Insurance Participation and Reforms, pp. 327-358. University of Chicago Press, 2012.

Bartik, Timothy, Who Benefits From State and Local Economic Development Policies? (Kalamazoo, MI: W.E. Upjohn Institute for Employment Research, 1991).

Beaudry, Paul, David A. Green, and Benjamin M. Sand. "The Great Reversal in the Demand for Skill and Cognitive Tasks." Journal of Labor Economics 34, no. S1 (2016): S199-S247.

Bertrand, Marianne, Emir Kamenica, and Jessica Pan. "Gender Identity and Relative Income within Households." The Quarterly Journal of Economics 130, no. 2 (2015): 571614.

Blau, Francine D., and Lawrence M. Kahn. "Female Labor Supply: Why Is the United States Falling Behind?." The American Economic Review 103, no. 3 (2013): 251-256.

Bound, John, and Richard V. Burkhauser, "Economic Analysis of Transfer Programs Targeted on People with Disabilities," in Orley Ashenfelter and David Card, eds., Handbook of Labor Economics, Volume 3 (Amsterdam: North- Holland, 1999).

Campolieti, Michele, "Moral hazard and disability insurance: On the incidence of hardto-diagnose medical conditions in the Canada/Quebec Pension Plan Disability Program," Canadian Public Policy 28, No. 3 (2002): pp. 419-441.

Campolieti, Michele. "Disability insurance benefits and labor supply: Some additional evidence." Journal of Labor Economics 22, no. 4 (2004): 863-889. 
Campolieti, Michele, "Disability insurance adjudication criteria and the incidence of hard-to-diagnose medical conditions," Contributions to Economic Analysis and Policy 5, No. 1 (2006), Article 15. Berkeley Electronic Press.

Campolieti, Michele, and Chris Riddell. "Disability policy and the labor market: Evidence from a natural experiment in Canada, 1998-2006." Journal of Public Economics 96, no. 3 (2012): 306-316.

Coile, Courtney. "Disability Insurance Incentives and the Retirement Decision: Evidence from the United States." In Social Security Programs and Retirement Around the World: Disability Insurance Programs and Retirement, pp. 45-80. University of Chicago Press, 2016.

Coile, Courtney, Kevin S. Milligan and David A. Wise. "Introduction to Social Security Programs and Retirement Around the World: Disability Insurance Programs and Retirement." In Social Security Programs and Retirement Around the World: Disability Insurance Programs and Retirement, pp. 1-44. University of Chicago Press, 2016.

Duggan, Mark and Scott A. Imberman (2009), "Why are the disability rolls skyrocketing? The contribution of population characteristics, economic conditions, and program generosity," in David M. Cutler and David A. Wise (eds.) Health at Older Ages: The causes and consequences of declining disability. Chicago: University of Chicago Press.

Eberstadt, Nicholas (2016), Men Without Work. West Conshohocken PA: Templeton Press.

Green, David A., and Benjamin M. Sand. "Has the Canadian labour market polarized?." Canadian Journal of Economics/Revue canadienne d'économique 48, no. 2 (2015): 612646.

Gruber, Jonathan. "Disability Insurance Benefits and Labor Supply." Journal of Political Economy 108, no. 6 (2000).

HRSDC (2011) Canada Pension Plan, Old Age Security, statistical bulletin. Human Resources and Social Development Canada, Catalogue Number SD16-1-PDF.

Maestas, Nicole, Kathleen J. Mullen, and Alexander Strand. "Does disability insurance receipt discourage work? Using examiner assignment to estimate causal effects of SSDI receipt." The American Economic Review 103, no. 5 (2013): 1797-1829.

Maestas, Nicole, Kathleen J. Mullen, and Alexander Strand. "Disability Insurance and the Great Recession." The American Economic Review 105, no. 5 (2015): 177-182.

Milligan, Kevin. "The long-run growth of disability insurance in the United States." In Social Security Programs and Retirement around the World: Historical Trends in 
Mortality and Health, Employment, and Disability Insurance Participation and Reforms, pp. 359-389. University of Chicago Press, 2012.

Milligan, Kevin, and Tammy Schirle. "Option Value of Disability Insurance in Canada." In Social Security Programs and Retirement Around the World: Disability Insurance Programs and Retirement, pp. 137-178. University of Chicago Press, 2016.

OCA (2016). $27^{\text {th }}$ Actuarial Report on the Canada Pension Plan as at 31 December 2015, Office of the Chief Actuary, Office of the Superintendent of Financial Institutions

Canada. Accessed February 23, 2017, at http://www.osfi-bsif.gc.ca/Eng/Docs/cpp27.pdf

SSA (2015). Annual Statistical Supplement, 2016. Tables accessed September 10, 2016 at https://www.ssa.gov/policy/docs/statcomps/supplement/2016/5d.html

Summers, Lawrence H. (2016), "Men Without Work," blog post dated September $26^{\text {th }}$. http://larrysummers.com/2016/09/26/men-without-work/ 
Figure 1: Disability Insurance Take-up Rates, Age 30-59

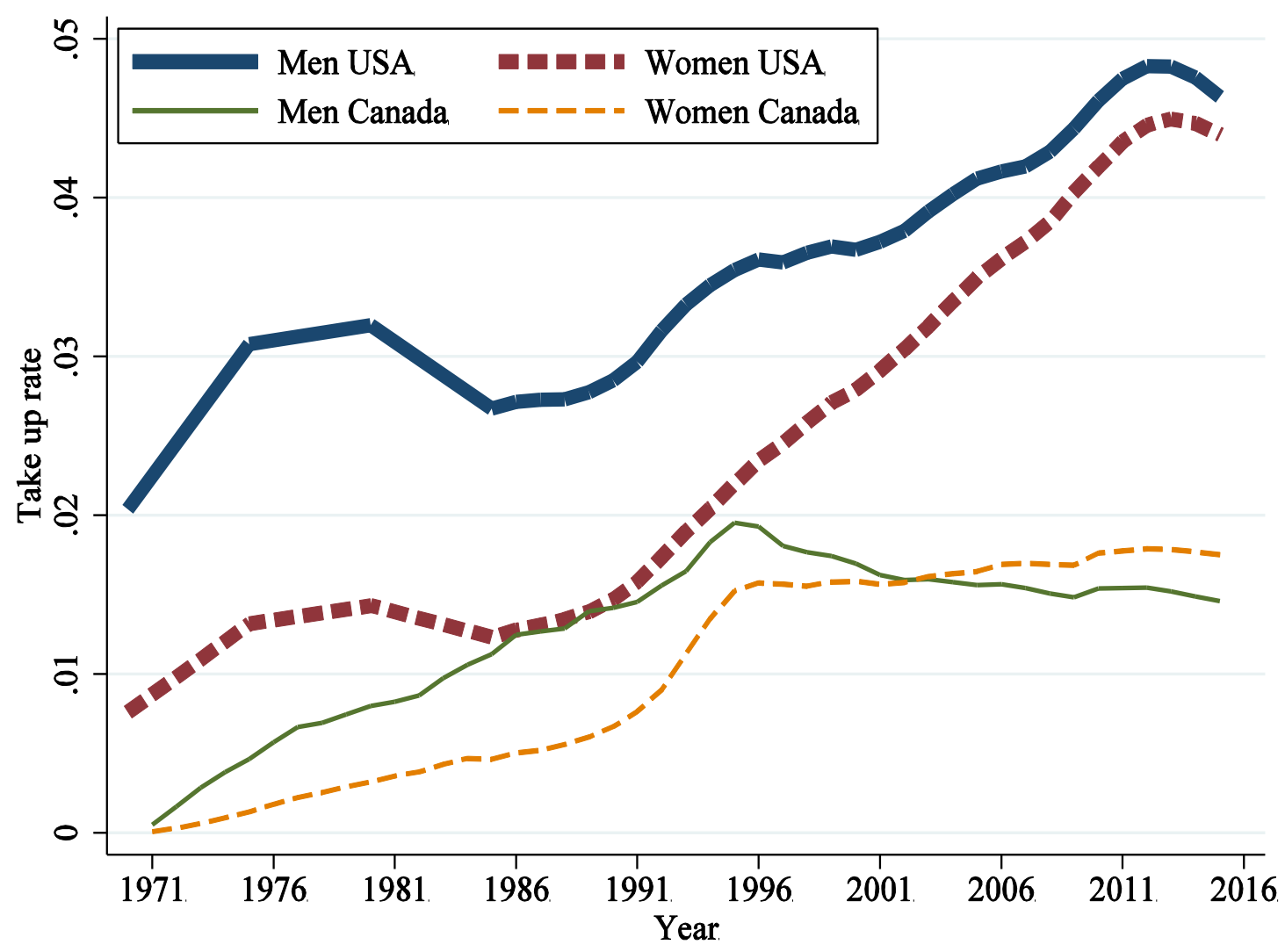

Sources: US data come from the Social Security Administration (numerator) and the Census Bureau (denominator). Canadian data come from Employment and Social Development Canada (numerator) and Statistics Canada (denominator). Canadian data exclude Quebec. 
Figure 2: Earnings and Disability Insurance Parameters
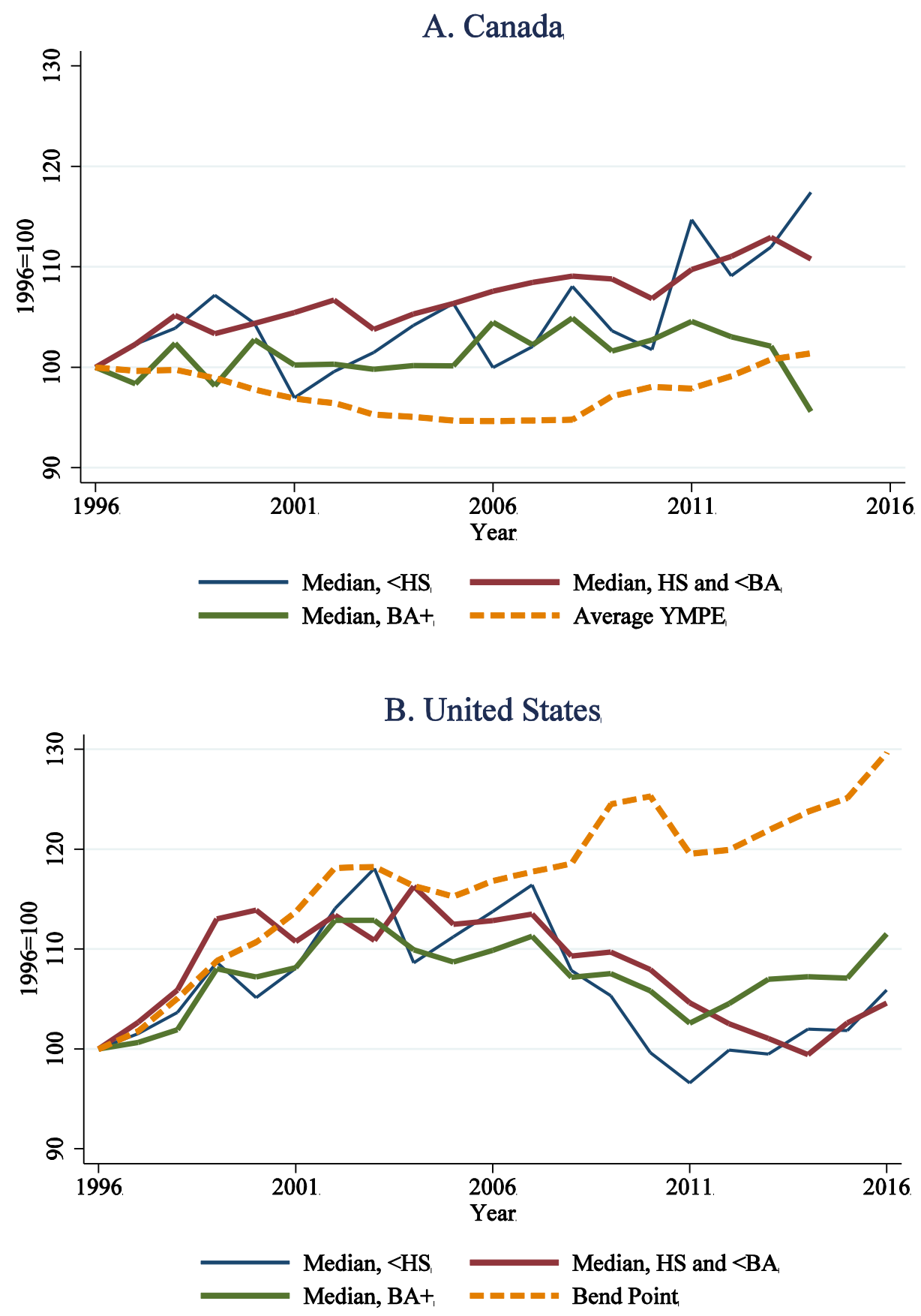

Source: CPS and SLID files, Bend point from Social Security Administration and YMPE from Employment and Social Development Canada. 
Figure 3: Earnings by Region in Canada and United States

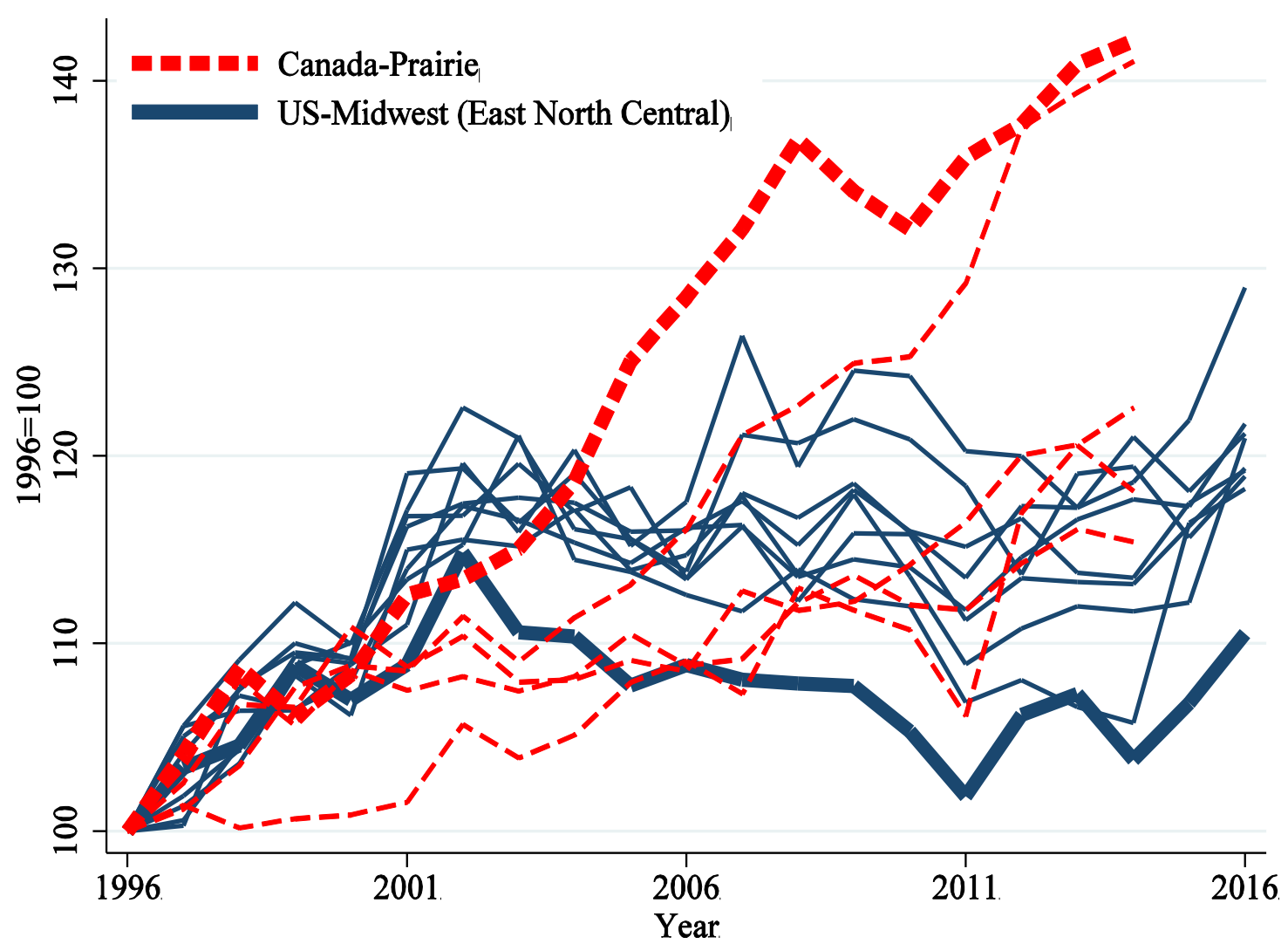

Sources: US data come from the CPS. Canadian data come from SLID/CIS. Each line represents one of the regions in our analysis - 5 in Canada and the 9 Census Divisions in the United States. Canadian regions are shown with dashed lines; US regions with solid lines. 
Figure 4: Disability Insurance Benefits by Year and Age
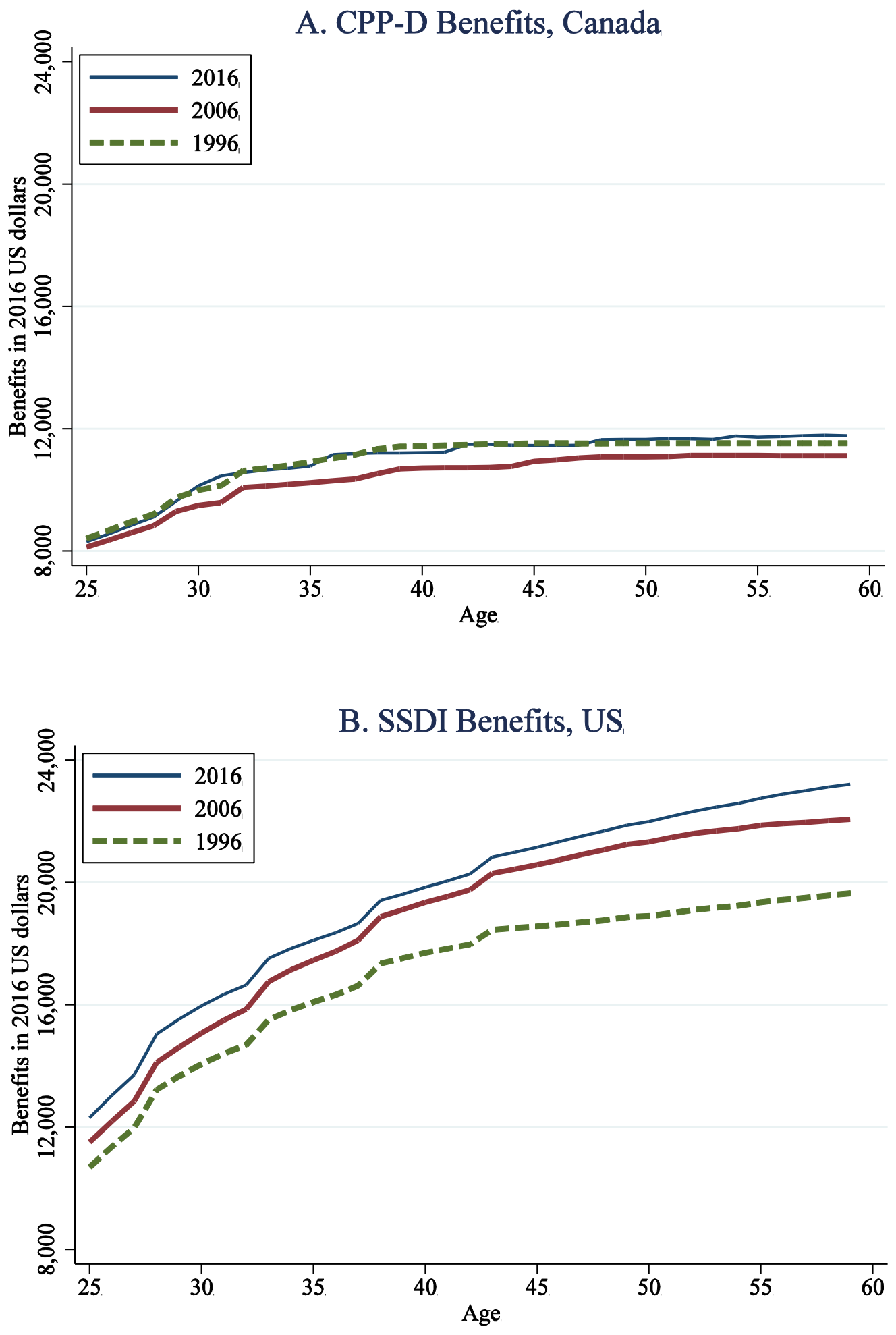

Notes: Graph shows simulated CPP-D and SSDI benefits for a common earnings history across years. Calculations by authors. 
Figure 5: Disability Insurance Take-up Rate by Education, ages 25-59
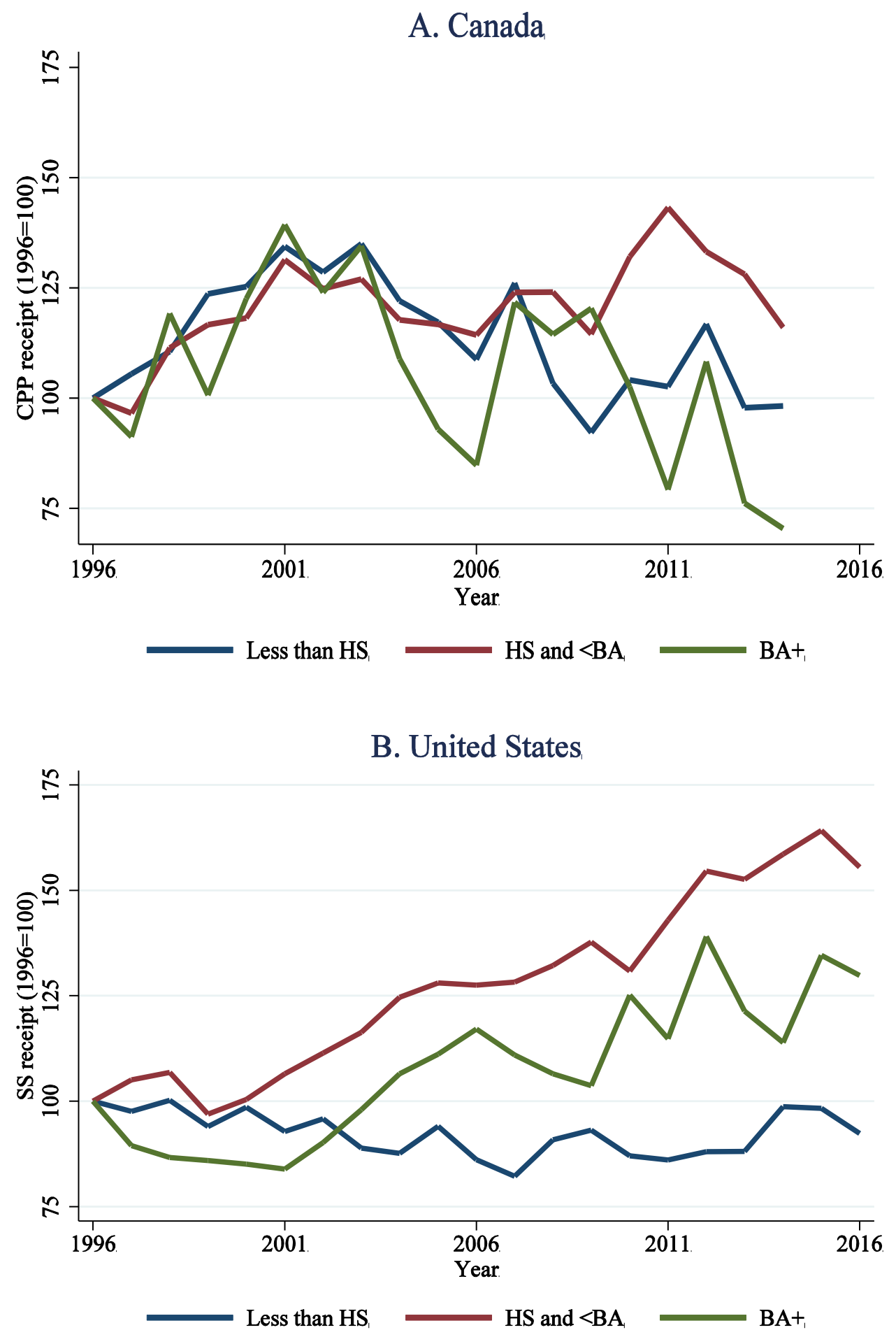

Notes: Data source is Current Population Survey for US and Survey of Labour and Income Dynamics / Canadian Income Survey for Canada. The sample includes all ages from 25 to 59. 
Figure 6: First Stage Relationships
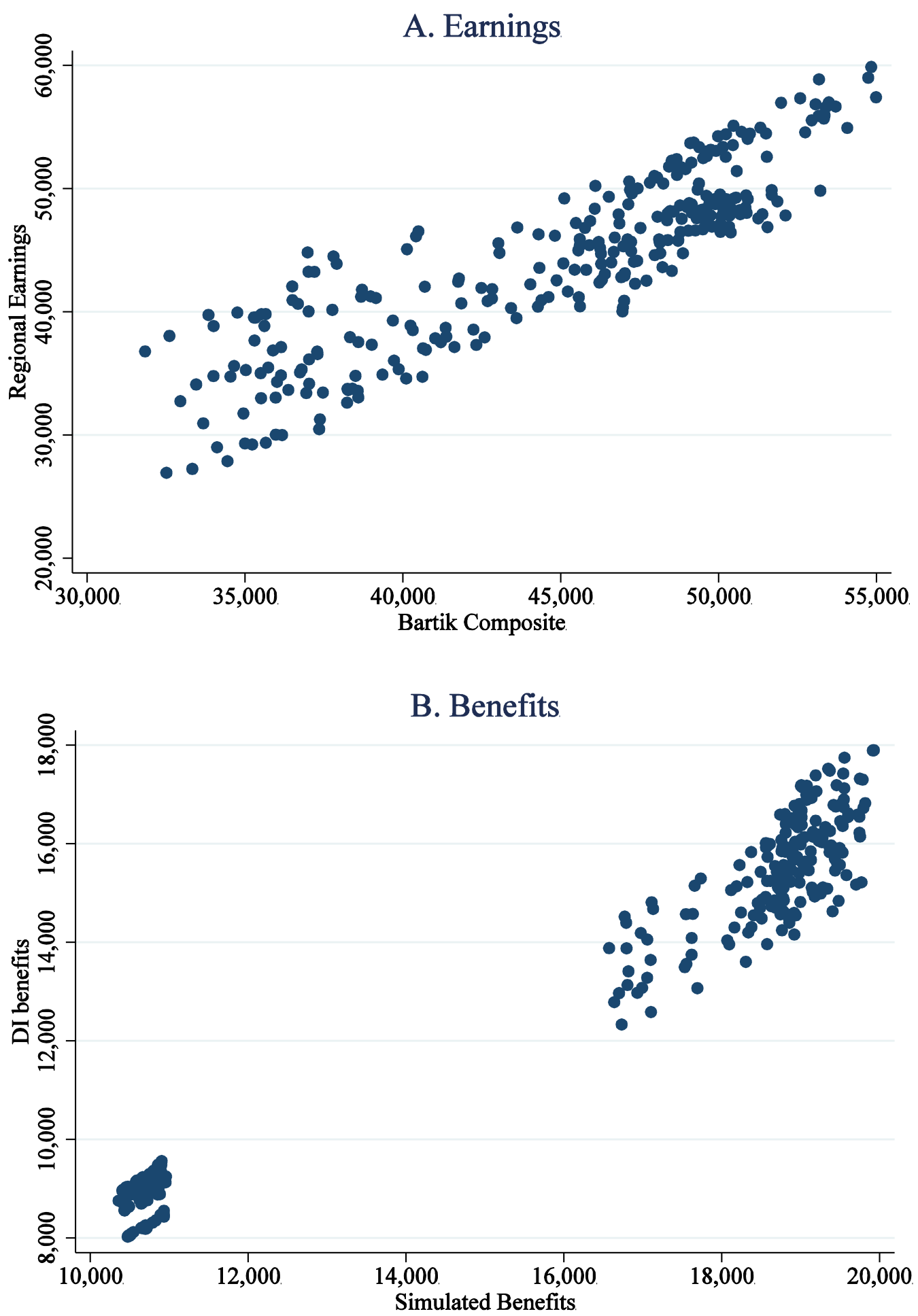

Notes: These scatter plots show data points at the region-year level as described in the text. All dollar values are 2016 US dollars. 
Figure 7: Counterfactual Simulations

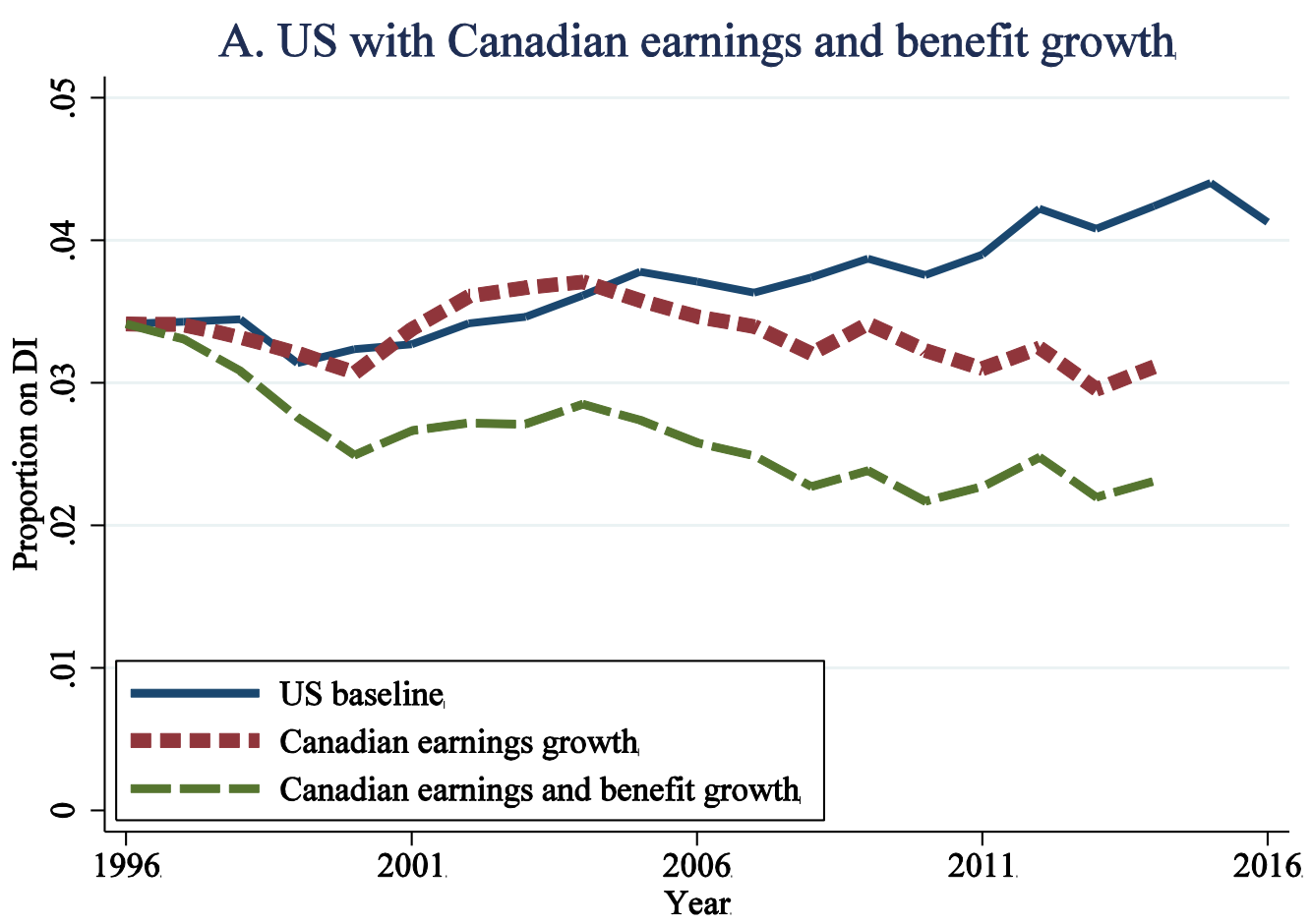

B. Canada Prairie with US Midwest earnings and benefit growth

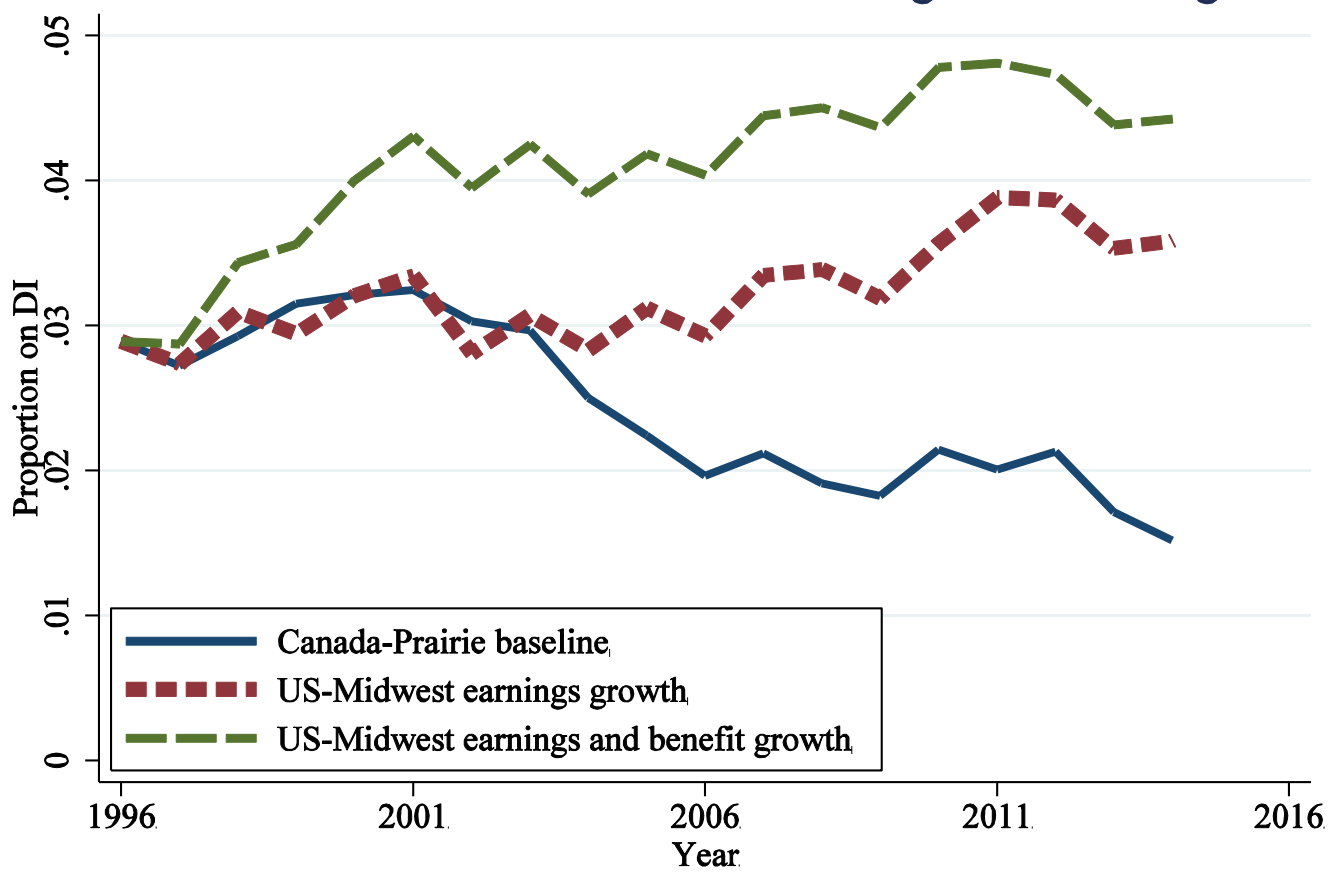

Notes: Simulations by authors. 
Table 1: Descriptive Statistics

\begin{tabular}{|c|c|c|c|c|c|c|c|c|}
\hline & (1) & Male & Female & Canada & (5) & $\begin{array}{c}\text { (6) } \\
\text { Less than } \\
\text { High School }\end{array}$ & $\begin{array}{l}\text { (7) } \\
\text { High School } \\
\text { / Some post- } \\
\text { secondary }\end{array}$ & $\begin{array}{c}(8) \\
\text { College or } \\
\text { University } \\
\text { Degree }\end{array}$ \\
\hline Observations & $2,407,603$ & $1,155,646$ & $1,251,957$ & 610,660 & $1,796,943$ & 304,846 & $1,427,143$ & 675,614 \\
\hline Benefit receipt & 0.036 & 0.034 & 0.039 & 0.027 & 0.037 & 0.072 & 0.041 & 0.014 \\
\hline Regional earnings & $\begin{array}{c}{[0.187]} \\
47,601 \\
{[23,015]}\end{array}$ & $\begin{array}{c}{[0.181]} \\
58,382 \\
{[25,428]}\end{array}$ & $\begin{array}{c}{[0.193]} \\
37,184 \\
{[13,995]}\end{array}$ & $\begin{array}{c}{[0.163]} \\
37,945 \\
{[13,656]}\end{array}$ & $\begin{array}{c}{[0.189]} \\
48,594 \\
{[23,545]}\end{array}$ & $\begin{array}{l}{[0.258]} \\
25,543 \\
{[8,617]}\end{array}$ & $\begin{array}{c}{[0.198]} \\
39,585 \\
{[10,736]}\end{array}$ & $\begin{array}{c}{[0.118]} \\
71,724 \\
{[24,715]}\end{array}$ \\
\hline Projected & 14,977 & 16,844 & 13,174 & 8,962 & 15,596 & 11,090 & 14,008 & 18,374 \\
\hline Benefits & {$[4,695]$} & {$[4,999]$} & {$[3,544]$} & {$[1,619]$} & {$[4,465]$} & {$[2,440]$} & {$[3,621]$} & {$[5,127]$} \\
\hline Replacement Rate & $\begin{array}{c}0.343 \\
{[0.088]}\end{array}$ & $\begin{array}{c}0.310 \\
{[0.078]}\end{array}$ & $\begin{array}{c}0.375 \\
{[0.086]}\end{array}$ & $\begin{array}{c}0.257 \\
{[0.074]}\end{array}$ & $\begin{array}{c}0.352 \\
{[0.085]}\end{array}$ & $\begin{array}{c}0.460 \\
{[0.111]}\end{array}$ & $\begin{array}{c}0.360 \\
{[0.057]}\end{array}$ & $\begin{array}{c}0.265 \\
{[0.055]}\end{array}$ \\
\hline $\begin{array}{l}\text { Married/Common } \\
\text { law }\end{array}$ & $\begin{array}{c}0.614 \\
{[0.487]}\end{array}$ & $\begin{array}{c}0.606 \\
{[0.489]}\end{array}$ & $\begin{array}{c}0.622 \\
{[0.485]}\end{array}$ & $\begin{array}{c}0.688 \\
{[0.463]}\end{array}$ & $\begin{array}{c}0.606 \\
{[0.489]}\end{array}$ & $\begin{array}{c}0.541 \\
{[0.498]}\end{array}$ & $\begin{array}{c}0.599 \\
{[0.490]}\end{array}$ & $\begin{array}{c}0.673 \\
{[0.469]}\end{array}$ \\
\hline Mortality rate & $\begin{array}{c}0.0029 \\
{[0.0023]}\end{array}$ & $\begin{array}{c}0.0037 \\
{[0.0026]}\end{array}$ & $\begin{array}{c}0.0021 \\
{[0.0017]}\end{array}$ & $\begin{array}{c}0.002 \\
{[0.0017]}\end{array}$ & $\begin{array}{c}0.003 \\
{[0.0024]}\end{array}$ & & & \\
\hline
\end{tabular}

Notes: Each column shows a different sample. All observations weighted using provided sample weights. Data source is the Current Population Survey for the US (1996-2016), and Survey of Labour and Income Dynamics (1996-2011) and Canadian Income Survey (2012-2014) for Canada. Death rate data come from the Human Mortality Database. Dollar values are reported in 2016 US dollars. The mortality rate is not shown for the education groups because it only varies at the year-age-gender-country level. 
Table 2: Basic OLS and IV results

\begin{tabular}{|c|c|c|c|c|}
\hline & $\begin{array}{l}(1) \\
\text { OLS }\end{array}$ & $\begin{array}{l}(2) \\
\text { IV }\end{array}$ & $\begin{array}{c}(3) \\
1^{\text {st }} \text { stage }\end{array}$ & $\begin{array}{c}(4) \\
\text { 1st stage }\end{array}$ \\
\hline Dependent variable & $\begin{array}{c}\mathrm{SS} / \mathrm{CQPP} \\
\text { receipt }\end{array}$ & $\begin{array}{c}\mathrm{SS} / \mathrm{CQPP} \\
\text { receipt }\end{array}$ & Log earnings & Log benefits \\
\hline Observations & $2,407,603$ & $2,405,728$ & $2,405,728$ & $2,405,728$ \\
\hline R-squared & 0.031 & 0.030 & 0.949 & 0.955 \\
\hline Log regional earnings & $\begin{array}{c}-0.005 \\
{[0.004]}\end{array}$ & $\begin{array}{c}-0.070 * * * \\
{[0.013]}\end{array}$ & & \\
\hline Log DI benefits & $\begin{array}{c}0.002 \\
{[0.007]}\end{array}$ & $\begin{array}{c}0.050 * * * \\
{[0.004]}\end{array}$ & & \\
\hline Log Composite earnings & & & $\begin{array}{c}0.644 * * * \\
{[0.043]}\end{array}$ & $\begin{array}{c}0.571 * * * \\
{[0.024]}\end{array}$ \\
\hline Log simulated DI benefits & & & $\begin{array}{c}0.062 * * * \\
{[0.014]}\end{array}$ & $\begin{array}{c}1.056 * * * \\
{[0.036]}\end{array}$ \\
\hline Canada & $\begin{array}{l}0.010 * \\
{[0.004]}\end{array}$ & $\begin{array}{c}0.004 \\
{[0.003]}\end{array}$ & $\begin{array}{c}-0.270 * * * \\
{[0.022]}\end{array}$ & $\begin{array}{c}-0.079 * * * \\
{[0.018]}\end{array}$ \\
\hline Male & $\begin{array}{c}-0.014^{*} \\
{[0.005]}\end{array}$ & $\begin{array}{c}0.013 \\
{[0.008]}\end{array}$ & $\begin{array}{c}0.240 * * * \\
{[0.037]}\end{array}$ & $\begin{array}{c}0.059 * \\
{[0.027]}\end{array}$ \\
\hline Married or common-law & $\begin{array}{c}-0.035^{* * * *} \\
{[0.002]}\end{array}$ & $\begin{array}{c}-0.035^{* * *} * \\
{[0.002]}\end{array}$ & $\begin{array}{c}0.003 * * \\
{[0.001]}\end{array}$ & $\begin{array}{c}0.004 * * * \\
{[0.001]}\end{array}$ \\
\hline Log death rate & $\begin{array}{c}0.018 * * * \\
{[0.001]}\end{array}$ & $\begin{array}{c}0.009 * * * \\
{[0.001]}\end{array}$ & $\begin{array}{c}-0.052 * * * \\
{[0.010]}\end{array}$ & $\begin{array}{c}-0.055 * * \\
{[0.013]}\end{array}$ \\
\hline High school graduate & $\begin{array}{c}-0.035^{* * *} * \\
{[0.006]}\end{array}$ & $\begin{array}{c}-0.015 \\
{[0.009]}\end{array}$ & $\begin{array}{c}0.178^{* *} \\
{[0.046]}\end{array}$ & $\begin{array}{l}-0.032 \\
{[0.024]}\end{array}$ \\
\hline College/university degree & $\begin{array}{c}-0.050 * * * \\
{[0.007]}\end{array}$ & $\begin{array}{c}-0.008 \\
{[0.013]}\end{array}$ & $\begin{array}{c}0.352 * * * \\
{[0.056]}\end{array}$ & $\begin{array}{c}-0.089^{*} \\
{[0.038]}\end{array}$ \\
\hline Age group dummies & YES & YES & YES & YES \\
\hline Year dummies & YES & YES & YES & YES \\
\hline $2^{\text {nd }}$ order interactions & YES & YES & YES & YES \\
\hline
\end{tabular}

Notes: Each column reports coefficients and standard errors from separate regressions with the indicated dependent variable. Regressions include the indicated control variables, plus dummies for region, and interactions between Canada and education, region, and male. The $2^{\text {nd }}$ order interactions include interactions between the age group dummies, the year dummies, and the Canada indicator. Robust standard errors are clustered by region. Stars indicate significance at the 1 percent ( 3 stars), 5 percent ( 2 stars), and 10 percent (1 star) levels of confidence. Data source is the Current Population Survey for the US, and Survey of Labour and Income Dynamics for Canada. 
Table 3: Canada compared to United States

\begin{tabular}{|c|c|c|c|c|}
\hline & $\begin{array}{c}\text { (1) } \\
\text { Main IV }\end{array}$ & $\begin{array}{c}\text { (2) } \\
\text { Just Canada }\end{array}$ & $\begin{array}{c}\text { (3) } \\
\text { Just US }\end{array}$ & $\begin{array}{c}\text { (4) } \\
\text { Just US }\end{array}$ \\
\hline Dependent variable & $\begin{array}{l}\text { SS/CQPP } \\
\text { receipt }\end{array}$ & CQPP receipt & SS receipt & SSDI receipt \\
\hline Observations & $2,405,728$ & 609,077 & $1,796,651$ & $1,484,087$ \\
\hline \multirow[t]{2}{*}{$2^{\text {nd }}$ order interactions } & Yes & No & No & No \\
\hline & \multicolumn{4}{|c|}{ Separate Earnings and Benefits } \\
\hline R-squared & 0.030 & 0.042 & 0.030 & 0.028 \\
\hline Log regional earnings & $\begin{array}{c}-0.070 * * * \\
{[0.013]}\end{array}$ & $\begin{array}{c}-0.035 * * \\
{[0.005]}\end{array}$ & $\begin{array}{c}-0.029 * * * \\
{[0.006]}\end{array}$ & $\begin{array}{c}-0.030 * * * \\
{[0.004]}\end{array}$ \\
\hline \multirow[t]{2}{*}{ Log DI benefits } & $\begin{array}{c}0.050 * * * \\
{[0.004]}\end{array}$ & $\begin{array}{l}-0.009 \\
{[0.006]}\end{array}$ & $\begin{array}{c}0.052 * * * \\
{[0.005]}\end{array}$ & $\begin{array}{c}0.040 * * * \\
{[0.003]}\end{array}$ \\
\hline & \multicolumn{4}{|c|}{ Replacement Rate } \\
\hline R-squared & 0.030 & 0.041 & 0.029 & 0.028 \\
\hline Replacement rate & $\begin{array}{c}0.160 * * * \\
{[0.016]}\end{array}$ & $\begin{array}{c}0.107 * * \\
{[0.018]} \\
\end{array}$ & $\begin{array}{c}0.146 * * * \\
{[0.014]} \\
\end{array}$ & $\begin{array}{c}0.116 * * * \\
{[0.008]}\end{array}$ \\
\hline
\end{tabular}

Notes: We report coefficients and standard errors from instrumental variable regressions with the indicated dependent variable. The regressions in each column, and in the top and bottom panel, are distinct. Regressions include same control variables as indicated Table 2, but the one-country samples do not include the Canada interactions or the age group by year interactions. Robust standard errors are clustered by region. Stars indicate significance at the 1 percent ( 3 stars), 5 percent ( 2 stars), and 10 percent ( 1 star) levels of confidence. Data source is the Current Population Survey for the US, and Survey of Labour and Income Dynamics for Canada. 
Table 4: Comparing across Demographic Samples

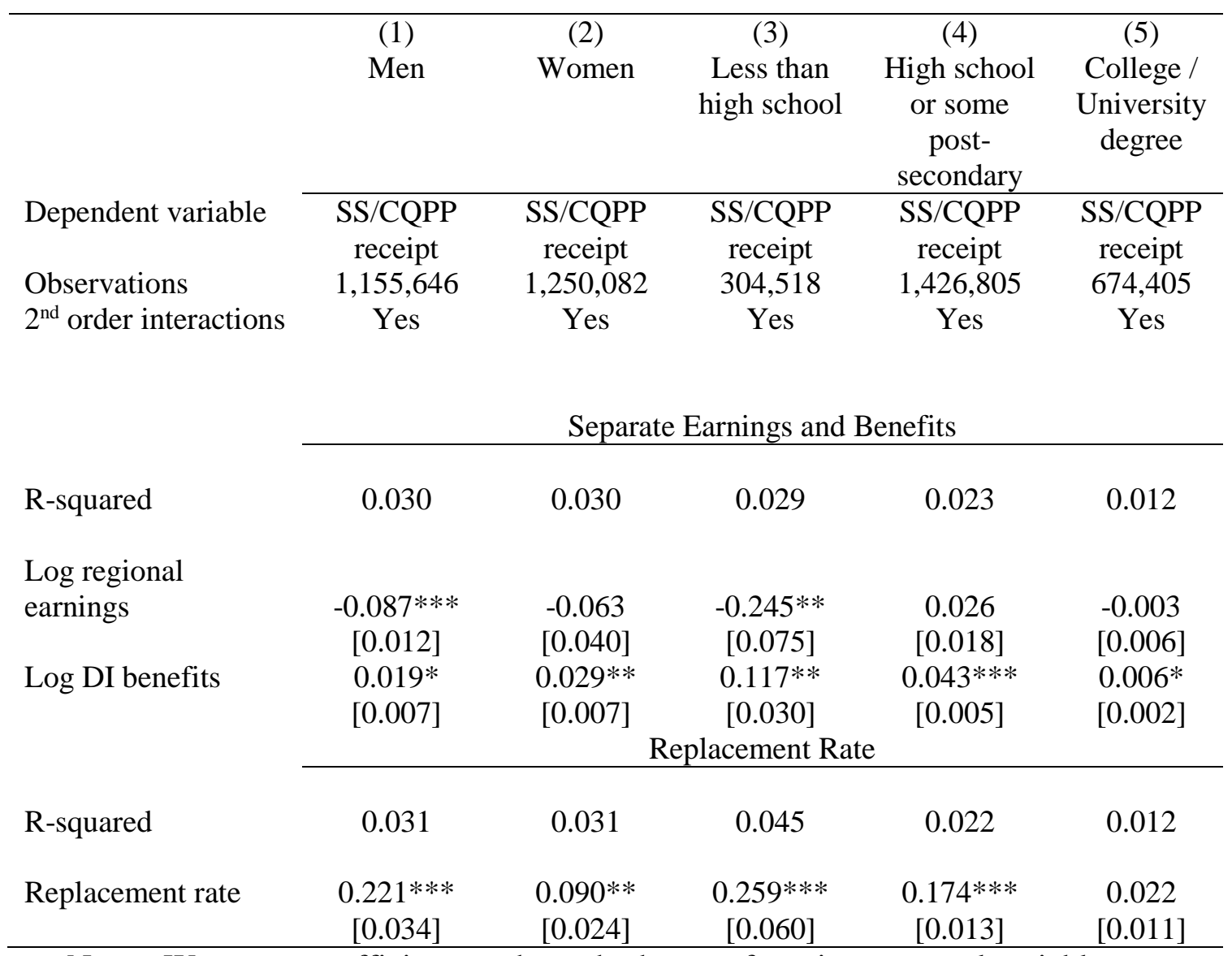

Notes: We report coefficients and standard errors from instrumental variable regressions with the indicated dependent variable. Each column has a different subsample. The regressions in each column, and in the top and bottom panel, are distinct. Regressions include same control variables as indicated in Table 2. Robust standard errors are clustered by region. Stars indicate significance at the 1 percent (3 stars), 5 percent ( 2 stars), and 10 percent (1 star) levels of confidence. Data source is the Current Population Survey for the US, and Survey of Labour and Income Dynamics for Canada. 
Table 5: Income Sources and Labor Supply

A. Income Sources

\begin{tabular}{|c|c|c|c|c|c|}
\hline Dependent variable & $\begin{array}{c}(1) \\
\text { SS/CQPP } \\
\text { receipt }\end{array}$ & $\begin{array}{c}(2) \\
\text { EI/UI } \\
\text { receipt }\end{array}$ & $\begin{array}{l}\quad(3) \\
\text { Welfare } \\
\text { receipt }\end{array}$ & $\begin{array}{c}(4) \\
\text { Workers' } \\
\text { Comp receipt }\end{array}$ & $\begin{array}{c}5) \\
\text { Any benefit } \\
\text { receipt }\end{array}$ \\
\hline $\begin{array}{l}\text { Observations } \\
2^{\text {nd }} \text { order interactions }\end{array}$ & $\begin{array}{c}2,405,728 \\
\text { Yes }\end{array}$ & $\begin{array}{c}2,405,728 \\
\text { Yes }\end{array}$ & $\begin{array}{c}2,405,728 \\
\text { Yes }\end{array}$ & $\begin{array}{c}2,405,728 \\
\text { Yes }\end{array}$ & $\begin{array}{c}2,405,728 \\
\text { Yes }\end{array}$ \\
\hline R-squared & $\begin{array}{c}0.036 \\
{[0.187]} \\
0.073\end{array}$ & $\begin{array}{c}0.051 \\
{[0.220]} \\
0.066\end{array}$ & $\begin{array}{c}0.017 \\
{[0.129]} \\
0.007\end{array}$ & $\begin{array}{c}0.011 \\
{[0.103]} \\
0.016\end{array}$ & $\begin{array}{c}0.130 \\
{[0.336]} \\
0.077\end{array}$ \\
\hline Replacement rate & $\begin{array}{c}0.160 * * * \\
{[0.016]}\end{array}$ & $\begin{array}{c}0.045 \\
{[0.038]}\end{array}$ & $\begin{array}{c}-0.047 \\
{[0.070]}\end{array}$ & $\begin{array}{c}0.021 \\
{[0.013]}\end{array}$ & $\begin{array}{c}0.275^{* *} \\
{[0.081]}\end{array}$ \\
\hline
\end{tabular}

B. Labor Supply

\begin{tabular}{|c|c|c|c|c|c|}
\hline Dependent variable & $\begin{array}{c}(1) \\
\text { Employed }\end{array}$ & $\begin{array}{c}(2) \\
\text { Employed } \\
\text { at work }\end{array}$ & $\begin{array}{c}(3) \\
\text { Employed } \\
\text { absent }\end{array}$ & $\begin{array}{c}\text { (4) } \\
\text { Unemployed }\end{array}$ & $\begin{array}{l}\text { (5) } \\
\text { Not in labor } \\
\text { force }\end{array}$ \\
\hline $\begin{array}{l}\text { Observations } \\
2^{\text {nd }} \text { order interactions }\end{array}$ & $\begin{array}{c}4,393,847 \\
\text { Yes }\end{array}$ & $\begin{array}{c}4,393,847 \\
\text { Yes }\end{array}$ & $\begin{array}{l}4,393,847 \\
\text { Yes }\end{array}$ & $\begin{array}{c}4,393,847 \\
\text { Yes }\end{array}$ & $\begin{array}{c}4,393,847 \\
\text { Yes }\end{array}$ \\
\hline $\begin{array}{l}\text { Mean } \\
\text { Std Deviation }\end{array}$ & $\begin{array}{c}0.772 \\
{[0.419]}\end{array}$ & $\begin{array}{c}0.743 \\
{[0.437]}\end{array}$ & $\begin{array}{c}0.029 \\
{[0.168]}\end{array}$ & $\begin{array}{c}0.045 \\
{[0.207]}\end{array}$ & $\begin{array}{c}0.183 \\
{[0.386]}\end{array}$ \\
\hline R-squared & 0.073 & 0.066 & 0.007 & 0.016 & 0.077 \\
\hline Replacement rate & $\begin{array}{c}0.004 \\
{[0.130]}\end{array}$ & $\begin{array}{c}-0.030 \\
{[0.129]}\end{array}$ & $\begin{array}{l}0.034 * * \\
{[0.011]}\end{array}$ & $\begin{array}{l}-0.087 * \\
{[0.036]}\end{array}$ & $\begin{array}{c}0.082 \\
{[0.105]}\end{array}$ \\
\hline
\end{tabular}

Notes: We report coefficients and standard errors from instrumental variable regressions with the indicated dependent variable. Each column has a different subsample. The regressions in each column, and in the top and bottom panel, are distinct. Regressions include same control variables as indicated in Table 2. Robust standard errors are clustered by region. Stars indicate significance at the 1 percent ( 3 stars), 5 percent ( 2 stars), and 10 percent (1 star) levels of confidence. Data source for the top panel is the CPS for the US, and the SLID/CIS for Canada. Data source for the bottom panel is the Current Population Survey for the US, and Labour Force Survey for Canada. 